\title{
MENERJEMAHKAN PERMAINAN BAHASA DALAM NOVEL ANAK JUDY MOODY, GIRL DETECTIVE
}

\author{
Indah Sulistyowati \\ STIBA Mentari Kupang \\ sulistyowati.indah86@gmail.com
}

\begin{abstract}
Abstrak
Novel anak merupakan suatu karya fiksi. Dalam novel anak banyak ditemukan permainan bahasa. Permainan bahasa tersebut terjadi pada tataran ejaan (permainan ejaan), bunyi (permainan bunyi), dan kata (permainan kata). Ketika menerjemahkan permainan bahasa dalam novel anak (karya fiksi), penerjemah harus memertahankan efek yang ditimbul oleh permainan bahasa tersebut. Penerjemah harus menggunakan prosedur penerjemahan yang tepat dalam menerjemahkan permainan bahasa tersebut. Dalam novel anak Judy Moody, Girls Detective, prosedur penerjemahan yang digunakan untuk menerjemahkan permainan ejaan adalah prosedur penerjemahan adaptasi. Sedangkan prosedur penerjemahan kuplet, padanan budaya, dan adaptasi digunakan untuk menerjemahkan permainan bunyi. Terakhir, prosedur penerjemahan parafrasa, kuplet, dan penjelasan tambahan digunakan untuk menerjemahkan permainan kata.
\end{abstract}

Kata kunci: novel anak, permainan bahasa, prosedur penerjemahan

\begin{abstract}
Children novel is a kind of fiction. There are many language plays found in a children novel. The langauge plays occur at the level of spelling (spelling play), sound (sound play), and word (word play). A translator has to maintain the efect of language plays when he translates the children novel (fiction). A translator has to apply appropriate translation prosedures in translating language plays. In children novel Judy Moody, Girls Detective, the translator uses adaptation prosedure to translate spelling plays. Moreover, couplet, cultural equivalent, and adaptation prosedure are used to translate the sound plays. At last, paraphrase, couplet, and addition prosedures are used to translate word plays.
\end{abstract}

Keywords: children novel, language play, translation prosedure

\section{PENDAHULUAN}

Novel (novel anak) merupakan salah satu bentuk karya sastra fiksi. Ketika melakukan penerjemahan, terutama teks fiksi, penerjemah menghadapi banyak masalah. Sebabnya, dalam teks fiksi banyak digunakan kata emotif, konotatif, idiom, slang, dan metafora (Wellek dan Warren, 1989; Sumardjo dan Saini, 1991). Selain mentransfer maksud dari penulis $\mathrm{TSu}$, penerjemah juga harus mempertahankan efek dari penggunaan kata emotif, konotatif, idiom, slang, serta metafora dalam TSu. Tindakan itu dilakukan agar pembaca TSa dapat merasakan efek yang serupa dengan pembaca TSu.

Permainan bahasa mendominasi sastra anak karena dengan permainan bahasa anak-anak dapat memperluas perbendaharaan kata. Selain itu, penulis novel juga dapat menyisipkan unsur humor melalui permainan bahasa. Hal itu menarik bagi anak-anak karena humor bersifat menyenangkan, serta dapat meningkatkan minat baca anak. 


\section{KONSEP DAN KERANGKA TEORI KONSEP}

\section{Konsep Padanan}

Padanan kata dalam terjemahan selalu dikaitkan dengan fungsi teks dan metode penerjemahan dan dalam penerjemahan konsep ini telah dianalisis, dievaluasi dan diperbincangkan dari berbagai perspektif yang berbeda. Terdapat dua pendapat yang berbeda terkait konsep padanan dalam terjemahan. Pendapat yang Pertama datang dari kelompok Vinay dan Darbelnet, Jakobson, Nida dan Taber, Catford, House, dan Baker. Vinay dan Darbelnet yang memandang padanan dalam kegiatan penerjemahan adalah padanan yang beorientasi mencari padanan sebagai suatu prosedur menciptakan kembali wujud kesamaan dari situasi yang sama sebagaimana situasi aslinya dengan ungkapan yang berbeda. Adapun pendapat yang lain berasal dari kubu Jakobson yang lebih menekankan padanan yang dimaksud dalam tterjemahan, yakni intralingual (dalam satu bahasa berupa parafrasa, interlingual (antara dua bahasa) dan intersemiotic (antar sistem tanda), dan menyatakan bahwa penerjemahan menyangkut dua pesan yang sepadan dalam dua kode (code) yang berbeda.

Dalam kaitannya dengan perpadanan, Catford mengidentifikasi dua jenis kesepadanan, yaitu (1) kesepadanan formal (formal equivalence) yang selanjutnya dirubah ke dalam istilah korespondensi formal (formal correspondence) dan (2) kesepadanan tekstual (textual equivalence) yang terjadi bila suatu teks atau sebagian dari teks bahasa target dalam situasi tertentu sepadan dengan teks atau sebagian teks bahasa sumber.

\section{Konsep Makna}

Istilah, "makna" memiliki pengertian yang sangat luas (Nasucha, 2001:152 $\square 153$ ) dan bahkan dipandang, sebagai suatu istilah yang paling kabur dan kontroversial dalam teori bahasa (Lihat Sumarsono, 1980:46). Kompleksnya pengertian makna disebabkan oleh kenyataan bahwa makna tidak saja berhubungan dengan masalah bahasa, tetapi juga berkaitan dengan masalah di luar bahasa, seperti budaya, pandangan hidup, aturan $\square$ aturan, dan norma $\square$ norma yang dimiliki oleh masyarakat pemakai bahasa tersebut. Kamus Besar Bahasa Indonesia (Depdikbud, 1993:619) mengartikan "makna" sebagai: "arti"; "maksud (pembicara atau penulis)"; dan "pengertian yang diberikan kepada suatu bentuk kebahasaan." Pengertian ini identik dengan konsep $\square$ konsep yang berhubungan dengan makna yang diberikan oleh Ulmann (1972) yakni name, sense, dan thing.

\section{Konsep Pergeseran Makna}

Konsep pergeseran makna yang dimaksud adalah perubahan yang ditentukan oleh adanya perbedaan struktural antara dua sistem bahasa yang terlibat dalam proses penerjemahan dan tindakan opsional (optional actions) yang ditentukan oleh 
preferensi personal dan stilistik. Pergeseran dimaksud terbagi menjadi 2 (dua), yaitu : (1) pergeseran mikro (micro shift) dan (2) pergeseran makro (macro shift). Pergeseran mikro bisa berujud pergeseran vertikal mengarah ke atas atau ke bawah dan pergeseran horizontal.

\section{Konsep Novel Anak}

Novel anak merupakan salah satu bentuk karya fiksi yang ditulis oleh orang dewasa untuk dibaca oleh anak-anak. Oleh karena itu, ragam dan laras bahasa yang digunakan disesuaikan dengan pembaca anak-anak (lihat Sumardjo\&Saini, 1986; Sarumpaet, 1975).

\section{KERANGKA TEORI}

Kegiatan menerjemahkan merupakan pengungkapan kembali pesan dan maksud dari BSu ke BSa dengan padanan yang terdekat, wajar, dan berterima bagi pembaca sasaran sesuai dengan maksud penulis TSu (Catford, 1965; Nida \& Taber, 1974; Newmark, 1988; Larson, 1989). Dalam menerjemahkan, penerjemah dapat mengungkapkan kembali pesan dan maksud ke BSa dengan bentuk (kata, frasa, klausa, kalimat, dan paragraf) yang berbeda (lihat Larson, 1989). Tindakan itu dilakukan karena adanya perbedaan yang dimiliki setiap bahasa, seperti sistem bahasa, struktur bahasa, dan karakteristik bahasa dalam hal pembentukan kata, urutan frasa, teknik untuk menghubungkan klausa menjadi kalimat, serta pemarkah wacana (lihat
Nida dan Taber, 1974).

Selain mengungkapkan kembali pesan dan maksud dengan padanan yang terdekat, penerjemah juga harus mengungkapkan kembali gaya penulisan $\mathrm{TSu}$, seperti ritme, rima, permainan bahasa, kesejajaran, dan penggunaan struktur tata bahasa yang tidak biasa (lihat Nida dan Taber, 1974). Gaya penulisan itu sering dijumpai pada karya satra (baca novel). Oleh karena itu, tidaklah mudah bagi penerjemah untuk menerjemahkan karya sastra karena penerjemah harus mengungkapkan kembali maksud dan gaya bahasa TSu secara bersamaan.

Novel anak merupakan karya sastra fiksi yang berbentuk prosa (lihat Sumardjo dan Saini, 1986). Dalam karya sastra banyak digunakan kata konotatif yang dapat menimbulkan nilai rasa pada pembaca (lihat Wellek, 1977; Zoest, 1991). Frege, seperti yang dikutip oleh Zoest (1991), mengemukakan bahwa dalam karya fiksi yang paling penting adalah "efek". Ketika menerjemahkan karya fiksi, penerjemah menitikberatkan pada efek yang ditimbulkan ketika pembaca sasaran membaca hasil terjemahan. Efek yang ditimbulkan ketika pembaca sasaran membaca TSa harus sama dengan efek yang ditimbulkan ketika pembaca sumber membaca TSu.

\section{PEMBAHASAN}

\section{Permainan Bahasa Novel Anak}

Karya sastra yang merupakan karya 
seni sering menyeleweng dari tatabahasa. Penyelewengan itu berupa manipulasi kebahasaan. Manipulasi kebahasaan dapat berupa penggunaan bahasa secara kreatif. Nilsen (1978) menyatakan bahwa penggunaan bahasa secara kreatif dan tidak biasa merupakan permainan bahasa. Nilsen (1978) menyatakan bahwa permainan bahasa adalah penggunaan bahasa secara kreatif dan tidak biasa, yang mempunyai tujuan lain atau di luar informasi dasar dari sebuah komunikasi.

Permainan bahasa juga dapat berupa eksploitasi dari bentuk-bentuk pengulangan (pengulangan bunyi, kata, ide), bentuk-bentuk penyimpangan yang mungkin berupa kemiripan (kemiripan bunyi, ejaan, atau bentuk), serta penggunaan hal-hal yang tidak lazim dan menyimpang dari yang seharusnya (katakata bentuk baru hasil proses morfologis, penggunaan tata bahasa yang salah, bentuk yang lazim atau salah). Biasanya permainan bahasa mempunyai implikasi untuk menghibur pembaca (lihat Tanto, 2010).

Permainan bahasa dapat berupa pengulangan atau repitisi, yaitu pengulangan bunyi atau pengulangan kata (lihat Nilsen, 1978). Menurut Keraf (1984, hlm. 127), "repetisi adalah pengulangan bunyi, suku kata, kata, atau bagian kalimat yang dianggap penting untuk memberi tekanan dalam sebuah konteks yang sesuai." Cook (2000) menambahkan bahwa permainan bahasa dapat digunakan sebagai metode untuk menambah perbendaharaan kata pada anak-anak. Oleh karena itu, dalam karya sastra anak banyak ditemukan permainan bahasa.

Bentuk pengulangan bunyi antara lain aliterasi, asonansi, dan rima. Aliterasi merupakan pengulangan bunyi konsonan yang sama, sedangkan asonansi merupakan pengulangan bunyi vokal yang sama (lihat Nilson, 1978). Selain itu, Nilson (1978) juga membagi rima menjadi tiga tipe yaitu rima maskulin, rima feminin, dan rima slant. Dari ketiga rima itu, rima maskulin merupakan rima yang paling umum dan paling banyak digunakan dalam permainan bahasa. Rima maskulin biasa muncul di awal atau akhir suku kata. Di samping itu, rima maskulin juga muncul di suku kata yang mendapat penekanan.

Selain pengulangan bunyi, permainan bahasa juga dapat berupa pengulangan kata. Bentuk pengulangan kata adalah anadiplosis, anafora, antimetabol, epanalepsis, epistrofa, politoton, dan tautotes.

Selain permainan bahasa yang berupa pengulangan bunyi dan kata, ada juga permainan bahasa yang berupa persamaan bunyi. Permainan bahasa ini disebut pun. Pun adalah tipe permainan bahasa yang didasarkan pada persamaan bunyi, tetapi terdapat perbedaan besar dalam maknanya (lihat Keraf, 1984).

\section{Prosedur Penerjemahan}

Prosedur penerjemahan diterapkan 
untuk menanggulangi kesulitan menerjemahkan pada tataran mikro (kata, kalimat, atau paragraf) (lihat Newmark, 1988).

\section{a. Transferensi}

Transferensi adalah "prosedur penerjemahan dengan cara mempertahankan kata dalam $\mathrm{BSu}$ di dalam teks BSa" (Newmark, 1988, hlm. 81). Newmark (1988) menyebut kata yang dipertahankan itu sebagai kata pinjaman (loan word).

\section{b. Transposisi}

Transposisi merupakan prosedur penerjemahan dengan mengubah kelas kata dan susunan kalimat tanpa mengubah maknanya untuk memperoleh terjemahan yang tepat (lihat Vinay dan Darbelnet dalam Munday, 2001). Prosedur penerjemahan ini menimbulkan pergeseran gramatikal.

\section{c. Sinonim}

Menurut Newmark (1978, hlm. 84), yang dimaksud sinonim merupakan "kata dalam BSa yang dekat dengan BSu dalam konteks tertentu". Prosedur ini bisa digunakan ketika penerjemah tidak menemukan padanan yang tepat dalam BSa.

\section{d. Parafrasa}

Parafrasa merupakan "prosedur yang dilakukan dengan cara memberikan penjelasan mengenai makna dari suatu bagian dari teks" (Newmark, 1977, hlm. 90). Prosedur ini dilakukan apabila suatu bagian tertentu mempunyai implikasi yang penting.

\section{e. Penjelasan tambahan}

Penjelasan tambahan merupakan prosedur penerjemahan dengan cara memberikan informasi tambahan dalam terjemahannya. "Penjelasan tambahan biasanya diterapkan pada kata-kata yang berhubungan dengan budaya (perbedaan budaya $\mathrm{BSu}$ dan $\mathrm{BSa}$ ), teknis (berhubungan dengan topik tertentu), atau kebahasaan (menjelaskan ketidakpatuhan suatu kata)" (Newmark, 1978, hlm 91).

\section{f. Padanan budaya}

Padanan budaya merupakan "prosedur penerjemahan dengan cara memadankan kata budaya BSu dengan kata budaya BSa" (Newmark, 1978, hlm. 82). Prosedur ini digunakan ketika menerjemahkan onomatope, idiom, simile, metafora, dan istilah yang sudah ada padanannya dalam BSa.

\section{g. Modulasi}

Prosedur penerjemahan modulasi dilakukan dengan memberikan padanan yang secara semantik berbeda sudut pandang artinya atau cakupan maknanya, tetapi dalam konteks yang bersangkutan memberikan pesan atau maksud yang sama (lihat Newmark, 1988; Vinay dan Darbelnet dalam Munday, 2001).

\section{h. Adaptasi}

Prosedur ini dilakukan apabila penerjemah menemukan situasi dalam budaya BSu yang tidak ditemukan dalam budaya BSa. Sebagai solusi atas permasalahan itu, Vinay dan Dalbernet (dalam Munday, 2001, hlm. 58) mengungkapkan bahwa 
"penerjemah harus menciptakan suatu situasi "baru" yang sepadan dengan situasi yang ada dalam TSu".

\section{i. Kuplet}

Kuplet adalah "prosedur penerjemahan dengan menggabungkan lebih dari satu teknik untuk memecahkan satu masalah penerjemahan" (Newmark, 1998, hlm. 91).

\section{Permainan Ejaan}

Permainan bahasa dalam novel anak Judy Moody, Girl Detective (TSu) banyak ditemukan. Permainan bahasa terjadi pada tiga tataran yang berbeda, yaitu ejaan, bunyi, dan kata.

\section{Tabel 1. Permainan Ejaan}

\begin{tabular}{|c|c|c|}
\hline No. & Inggris & ia \\
\hline 1 & $\begin{array}{l}\text { Stink tilted his head, reading upside down. He } \\
\text { was trying to figure out the words Judy had } \\
\text { just added. "'Have you seen this goo?"” } \\
\text { "'Have you seen this dog."” } \\
\text { "Oh. Your D looks like an O." }\end{array}$ & $\begin{array}{l}\text { Stink memiringkan kepalanya, membaca tulisan } \\
\text { secara terbalik. Dia mencoba membaca tulisan } \\
\text { Judy. "Apa kamu pernah melihat anting ini?" } \\
\text { "'Apa kamu pernah melihat anjing ini?", } \\
\text { "Oh. Huruf J-mu terlihat seperti T." }\end{array}$ \\
\hline 2 & $\begin{array}{l}\text { "'Drawer?" Stink asked, squinching up his } \\
\text { face. } \\
\text { "'Reward!"” said Judy. "We have to offer big } \\
\text { bucks so that anyone who has seen Mr. Chips } \\
\text { or has any information on his whereabouts will } \\
\text { call the police. Rule Number One of being a } \\
\text { good detective is don't be afraid to ask for } \\
\text { help." }\end{array}$ & $\begin{array}{l}\text { "KAIDAH??" tanya Stink sambil mengerutkan } \\
\text { dahinya. } \\
\text { "'HADIAH!" kata Judy. "Kita harus menawarkan } \\
\text { sejumlah uang agar siapapun yang melihat Mr. } \\
\text { Chips atau yang mempunyai informasi tentang } \\
\text { keberadaannya akan menelepon polisi. Peraturan } \\
\text { Nomor Satu menjadi detektif yang baik adalah } \\
\text { jangan segan meminta bantuan." }\end{array}$ \\
\hline 3 & $\begin{array}{l}\text { "The first three letters were K-G-B," said } \\
\text { Rocky. } \\
\text { "K-F-C," said Frank. } \\
\text { "K-L-F," said Stink. "Or E-L-F." }\end{array}$ & $\begin{array}{l}\text { "Tiga huruf pertama adalah K-F-C," kata Rocky. } \\
\text { "K-N-C," kata Frank. } \\
\text { "K-I-N," kata Stink. “Atau J-I-N." }\end{array}$ \\
\hline
\end{tabular}

Goo $::$ anting

Guna menciptakan permainan ejaan yang serupa dalam BSa, dipuutuskan untuk tidak mempertahankan makna kata goo (cairan pekat). Apabila makna kata goo tetap dipertahankan, maka efek permainan ejaan akan hilang. Oleh karena itu, diciptakan permainan ejaan yang serupa dalam BSa, yaitu menggunakan kata anting sebagai padanan goo, sehingga efek permainan ejaan dalam $\mathrm{TSu}$ dapat juga dirasakan dalam permainan bahasa TSa.
Dengan demikian, diterapkan prosedur penerjemahan adaptasi. Permainan ejaan dalam TSa merupakan adaptasi dari permainan ejaan dalam TSu meskipun maknanya berubah. Hal itu dilakukan untuk mempertahankan permainan ejaan.

\section{Drawer :: kaidah}

Alih-alih memadankan drawer dengan laci, penulis memutuskan untuk memadankannya dengan kaidah demi 
mempertahankan permainan ejaan yang ada di TSu. Dipilih kata kaidah karena tidak ditemukan kata dalam bahasa Indonesia yang mempunyai sifat yang sama dengan ejaan kata reward, yaitu apabila dibaca dari kanan ke kiri membentuk kata baru yang mempunyai arti. Oleh karena itu, dipiilih kata kaidah karena mempunyai ejaan paling mendekati kata hadiah walaupun maknanya berbeda dari drawer. Hal itu dilakukan demi mempertahankan permainan ejaan.

Dengan memadankan drawer dengan kaidah, maka makna harfiah kata drawer (laci) memang tidak tersampaikan. Meskipun demikian, efek permainan ejaan dalam TSu dapat tersampaikan dengan baik dalam TSa. Selain itu, makna dari kata drawer (laci) tidak memegang peranan penting dalam konteks kisah. Permainan ejaan yang ditimbulkan dari penggunaan kata reward dan drawer yang lebih berperan penting. Dengan memadankan drawer dengan kaidah, maka penulis menerapkan prosedur penerjemahan adaptasi.

$E-L-F \because \because J-I-N$

Penulis memutuskan untuk memadankan elf dengan jin, dengan pertimbangan kata jin terdiri dari tiga huruf (J-I-N), sehingga sesuai untuk menyatakan huruf belakang pelat nomor mobil. Dengan memilih J-I-N sebagai padanan E-L-F, penulis menerapkan prosedur penerjemahan adaptasi. Dalam kasus ini penulis mengadaptasi permaianan ejaan dalam TSu dengan permainan ejaan dalam TSa walaupun terjadi perubahan makna. Hal itu dilakukan untuk mempertahankan permainan ejaan.

\section{Permainan Bunyi}

Permainan bunyi diklasifikasi menjadi dua: permainan bunyi dengan padanan BSa dan permainan bunyi dengan mempertahankan BSu.

Tabel 2. Permainan bunyi dengan padanan BSa

\begin{tabular}{|c|l|l|}
\hline No. & \multicolumn{1}{|c|}{ Inggris } & \multicolumn{1}{|c|}{ Indonesia } \\
\hline 4 & $\begin{array}{l}\text { "Well, um...don't laugh, but-“ } \\
\text { "Ha! Ju-dy is scare-dy!" Stink chimed. } \\
\text { "You hid it under here because it's scary. } \\
\text { You're scared of a Nancy Drew } \\
\text { nightmare!" }\end{array}$ & $\begin{array}{l}\text { "Yaaa...mm..jangan ketawa ya, tapi..." } \\
\text { "Kamu Judy memang ban-ci!" sela Stink. } \\
\text { seram. Kamu takut dengan cerita horor Nancy Drew!" }\end{array}$ \\
\hline 5 & $\begin{array}{l}\text { "More like the Case of the Stolen } \\
\text { Candy," said Judy. "I hid a bag of } \\
\text { gummy candy in my moose's tummy. } \\
\text { But now the candy's not there. Presto- } \\
\text { change-o gonzo, just like that." }\end{array}$ & $\begin{array}{l}\text { "Lebih tepatnya Kasus Permen yang Dicuri," kata Judy. } \\
\text { "Akut boneka Pausku. Tetapi sekarang permen itu sudah } \\
\text { tidak ada. Abra ka dabra, hilang begitu saja." }\end{array}$ \\
\hline 6 & $\begin{array}{l}\text { "Moose. Mouse. Mice. My tongue got } \\
\text { twisted. And I know how much you like } \\
\text { those gummy mice. More than gummy } \\
\text { scabs and gummy frog legs." }\end{array}$ & $\begin{array}{l}\text { "Paus. Tikus. Kuskus. Lidahku keseleo. Dan aku tahu } \\
\text { kamu sangat menyukai permen gummy kuskusmu } \\
\text { melebihi permen gummy plester atau gummy kaki } \\
\text { katak." }\end{array}$ \\
\hline 7 & $\begin{array}{l}\text { "Flush 'n' Flo?" said Stink. } \\
\text { "Push 'n' Go," said Rocky. } \\
\text { "Flash 'n' Glo," said Frank. }\end{array}$ & $\begin{array}{l}\text { "Gebyur byur?" kata Stink. } \\
\text { "Guyur yur," kata Rocky. } \\
\text { "Banjur jur," kata Frank. }\end{array}$ \\
\hline
\end{tabular}

Scare-dy :: ban-ci 
Ungkapan scare- $d y$ dalam novel diambil dari idiom scaredy-cat yang mempunyai makna 1 . one who is excessively fearful; 2. someone who is easily frightened (diakses dari laman http:// www.thefreedictionary.com/ scaredy-cat tanggal 21 Desember 2011). Dengan menggunakan idiom scare- $d y$, penulis novel melakukan permainan bahasa yang berupa pengulangan bunyi [di] (-dy) pada $\mathrm{Judy}$ dan scare-dy. Pengulangan bunyi [di] itu termasuk dalam rima maskulin karena pengulangan terjadi di akhir silabel (lihat Nilsen, 1978, hlm. 81).

Idiom scare-dy pada ungkapan dapat dipadankan dengan penakut. Menurut TBI (2008, hlm. 487), salah satu sinonim kata penakut adalah "banci." penulis memutuskan untuk memadankan scare- $d y$ dengan banci yang diakhiri dengan bunyi [i]. Perlu dicatat bahwa banci dalam kasus ini bermaka kiasan 'penakut'. Dengan demikian, banci berima dengan Judy sama halnya dengan scare-dy yang berima dengan Judy. Selain itu, saya tidak menemukan idiom dalam bahasa Indonesia yang bermakna 'penakut'. Oleh karena itu, penulis memilih banci yang digunakan dalam makna kiasan.

Dengan memilih kata banci sebagai padanan scare- $d y$, penulis menerapkan prosedur penerjemahan kuplet, yaitu parafrasa dan transposisi. Prosedur parafrasa digunakan karena tidak ditemukan idiom dalam BSa yang mempunyai makna sama dengan idiom dalam BSu. Oleh karena itu diputuskan untuk memarafrasakan idiom TSu. Sementara itu, prosedur transposisi dilakukan dengan mengubah struktur permainan bunyi. Struktur permainan bunyi TSu yang terjadi pada tataran silabel (-dy [di]) diubah menjadi pada tataran bunyi vokal ([i]) di TSa.

\section{Presto-change-o gonzo :: abra ka dabra}

Melalui ungkapan Presto-change-o gonzo, penulis novel melakukan permainan bunyi, yaitu berupa asonansi [o]. Selain itu, di dalam ungkapan itu juga terdapat katakata yang mengalami proses kreatif, yaitu kata change-o dan gonzo. Change-o diperoleh dari kata change, yang oleh ditambah bunyi [o] di akhir kata. Sedangkan, kata gonzo diperoleh dari kata gone yang kemudian ditambah bunyi $[\mathrm{z}]$ dan [o] di akhir kata. Proses kreatif yang dilakukan penulis novel bertujuan untuk menimbulkan asonansi [o] yang terjadi pada kata presto, change-o, dan gonzo.

Menurut konteks cerita, ungkapan itu bermakna gummy yang disembunyikan Judy dalam perut boneka pausnya hilang begitu saja. Sebagai padanan atas ungkapan itu, penulis memutuskan untuk menggunakan ungkapan abra ka dabra. Ungkapan itu merupakan mantra yang sering digunakan oleh pesulap ketika mereka melakukan trik. Salah satu trik dalam sulap yang cukup dikenal adalah trik kecepatan tangan. Dalam trik itu, pesulap menggunakan kecepatan tangan untuk menghilangkan suatu benda dengan cepat 
(diakses dari laman http://id.wikipedia.org/ wiki/Sulap tanggal 4 Januari 2012). Hal itu serupa dengan yang terjadi pada gummy milik Judy yang hilang begitu saja. Selain itu, dalam abra ka dabra terdapat asonansi [a] (abra ka dabra). Dengan demikian, penulis mempertahankan makna 'hilang dengan cepat' dan permainan bunyi asonansi.

Dengan memilih abra ka dabra

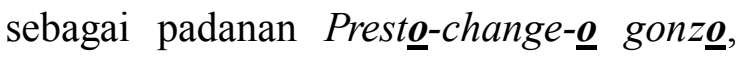
saya menerapkan prosedur penerjemahan padanan budaya. Presto-change-o gonzo digunakan oleh pembaca $\mathrm{TSu}$ untuk mengungkapkan 'hilang dengan cepat'. Sementara itu, untuk mengungkapkan makna yang sama dalam TSa, penulis menggunakan ungkapan abra ka dabra yang merupakan mantra dalam sulap.

Moose, mouse, mice :: paus, tikus kuskus.

Melalui kata moose [mu:s], mouse [mavs], dan mice [maIs], penulis novel ingin mengungkapkan suatu permainan bunyi berupa aliterasi [m] pada awal kata dan [s] pada akhir kata. Demi mempertahankan permainan bunyi, penulis putuskan untuk memadankan moose, mouse, dan mice dengan paus, kuskus, dan tikus. Ketiga nama binatang itu mempunyai bunyi vokal $[\mathrm{u}]$. Persamaan bunyi vokal itu akan menimbulkan asonansi. Meskipun demikian, pengulangan bunyi yang ada di TSa tidak sama dengan yang ada di TSu. Dalam TSu pengulangan bunyi berupa aliterasi, sedangkan dalam TSa berupa asonansi.
Dengan memilih paus, tikus, dan kuskus sebagai padanan moose, mouse, dan mice, penulis menerapkan prosedur penerjemahan adaptasi. Penulis mengadaptasi permainan bunyi $\mathrm{TSu}$ dengan permainan bunyi TSa meskipun maknanya berubah. Hal itu dilakukan demi mempertahankan permainan bunyi.

Flush 'n' flo; push 'n' go; flash ' $n$ ' glow :: gebyur byu; guyur yur; banjur jur.

Dalam ungkapan flush ' $n$ ' flo; push 'n' go; dan flash ' $n$ ' glow terdapat permainan bunyi berupa, yaitu:

1. Aliterasi [f] dan [1] pada kata flush, flo, dan flash,

2. Aliterasi [J] pada kata flush, push, dan flash, dan

3. Asonansi [o] pada kata flo, go, dan glo.

Permainan bahasa yang diciptakan dalam teks sasaran berupa rima maskulin, berbeda dengan yang ada di TSu yaitu aliterasi dan asonansi. Rima maskulin itu berupa pengulangan silabel terakhir. Demi mempertahankan efek permainan bunyi yang ada dalam teks sumber, penulis memutuskan untuk memadankan ungkapan itu dengan gebyur byur, guyur yur, dan banjur jur. Menurut TBI (2008, hlm. 463), kata gebyur, guyur, dan banjur merupakan sinonim dari menyiram .

Dalam kasus ini, penulis memilih padanan yang berhubungan dengan makna 'menyiram'. Selain itu, penulis juga menekankan makna 'menyiram'. Penekanan makna berupa pengulangan silabel terakhir kata gebyur, guyur, dan 
banjur. Ungkapan itu mengandung makna apabila air disiramkan secara berulangulang, maka kotoran akan hilang dan menjadi bersih.

Dalam kasus ini terjadi perubahan makna yaitu dari "ungkapan yang berhubungan dengan kloset atau toilet" menjadi "menyiram". Hal itu dilakukan untuk mempertahankan permainan bunyi. Meskipun demikian, citra yang ditampilkan serupa yaitu 'menyiram kotoran hingga bersih'. Selain itu, penulis mengadaptasi permainan bunyi dalam $\mathrm{TSu}$ dengan permainan bunyi TSa. Dengan demikian, diterapkan prosedur penerjemahan kuplet, yaitu modulasi dan adaptasi.

Tabel 3. Permainan bunyi dengan mempertahankan BSu

\begin{tabular}{|c|l|l|}
8 & $\begin{array}{l}\text { "I said Agent Dragnet, not Agent Dragonfly," } \\
\text { said Frank. }\end{array}$ & $\begin{array}{l}\text { "Aku bilang Agen Dragnet, bukan Agen Dragonfly," } \\
\text { kata Frank. }\end{array}$ \\
\hline
\end{tabular}

Dragonfly :: Dragonfly

Melalui nama diri Dragnet dan Dragonfly, penulis novel melakukan permainan bunyi berupa pengulangan bunyi silabel [dra] (['drægnət] dan ['drægənflaI]). Pengulangan bunyi itu termasuk dalam rima maskulin karena pengulangan terjadi pada silabel yang mengalami penekanan. Dengan mempertahankan nama diri dalam BSu, penulis menerapkan prosedur penerjemahan transferensi. Hal itu dilakukan untuk tetap mempertahankan rima yang ada pada TSu.

\section{Permainan Kata}

Tabel 4. Permainan Kata

\begin{tabular}{|c|c|c|}
\hline No. & Inggris & Indonesia \\
\hline 9 & $\begin{array}{l}\text { Then, late Friday afternoon, something } \\
\text { happened. Something big. Judy was smack- } \\
\text { dab in the middle of an important case - } \\
\text { Nancy Drew book \#15, that is: The Haunted } \\
\text { Bridge - when the loudspeaker crackled. Judy } \\
\text { jumped five feet and yelled, "Yurp," wrecking } \\
\text { the silent in the silent reading. }\end{array}$ & $\begin{array}{l}\text { Kemudian, pada Jumat sore, sesuatu terjadi. Sesuatu } \\
\text { yang sangat besar. Judy terlibat dalam sebuah kasus } \\
\text { yang sangat penting, seperti dalam buku Nancy } \\
\text { Drew \#15, yaitu The Haunted Bridge, ketika } \\
\text { pengeras suara bergemeretak. Judy melompat } \\
\text { terperanjat satu setengah meter karena kaget dan } \\
\text { berteriak, "Aaaa!!!," memecah keheningan di tengah } \\
\text { keheningan kelas. }\end{array}$ \\
\hline 10 & $\begin{array}{l}\text { "The phone number was like } 1-800-\mathrm{UN}- \\
\text { DOG," said Rocky. } \\
\text { "'UN-DOG?"” said Judy. "Are sure it didn't } \\
\text { say 'UN-CLOG?"” } \\
\text { "1-800-UNDER-DOG!" said Stink. } \\
\text { "Great," said Judy. "Let's all take an } \\
\text { Underdog Super Energy Pill and find a } \\
\text { phone booth and change into super-heroes. } \\
\text { Then we'll find Mr. Chips." }\end{array}$ & $\begin{array}{l}\text { "Kayaknya nomor teleponnya 1-800-UN-DOG," } \\
\text { kata Rocky. } \\
\text { "'UN-DOG?", kata Judy. "Apa kamu yakin } \\
\text { tulisannya ngga 'UN-CLOG?"” } \\
\text { "1-800- UNDER-DOG!" kata Stink. } \\
\text { "Bagus," kata Judy. "Ayo kita minum Pil Energi } \\
\text { Super Super-hero Underdog, lalu cari bilik } \\
\text { telepon umum dan berubah menjadi super-hero. } \\
\text { Pasti kita akan menemukan Mr. Chips." }\end{array}$ \\
\hline 11 & $\begin{array}{l}\text { "So the fingerprint is just a red herring," Judy } \\
\text { said. } \\
\text { "What's a red herring?" asked Stink. } \\
\text { "A PU stinky fish," said Rocky. } \\
\text { "No, a false clue," Judy told them. "To throw } \\
\text { us off." }\end{array}$ & $\begin{array}{l}\text { "Jadi sidik jari itu hanya sekedar petunjuk palsu," } \\
\text { kata Judy. } \\
\text { "Apa itu petunjuk palsu?" tanya Stink. } \\
\text { "Petunjuk palsu itu petunjuk tiruan, ngga asli," kata } \\
\text { Rocky. } \\
\text { "Bukan, tapi petunjuk yang menyesatkan," kata Judy } \\
\text { kepada mereka, "yang membuat kita bingung." }\end{array}$ \\
\hline
\end{tabular}

The silent reading $::$ keheningan kelas. 
Menurut konteks kisah, Judy sedang serius memikirkan kasus hilangnya $\mathrm{Mr}$. Chips di dalam ruang kelas. Ketika dia sedang serius memikirkan hal itu, tiba-tiba terdengar suara gemeretak pengeras suara yang membuat Judy tersentak kaget dan berteriak. Saat itu, kelas Judy sedang dalam keadaan hening. Karena teriakan Judy, kelas itu menjadi tidak hening lagi. Penulis memutuskan untuk memadankan silent reading dengan frasa keheningan kelas. Hal itu bertujuan untuk tetap mempertahankan permainan bahasa berupa pengulangan kata tipe tautotes.

Dengan memilih keheningan kelas sebagai padanan dari silent reading, penulis menerapkan prosedur penerjemahan kuplet, yaitu modulasi dan parafrasa. Pada kasus ini terjadi perubahan makna dari "membaca dalam hati" menjadi "keheningan kelas". Meskipun demikian, citra yang ditampilkan yaitu 'keadaan hening' masih dapat tersampaikan.

\section{Underdog :: Super-hero Underdog.}

Penulis memutuskan untuk memberikan penjelasan tambahan berupa kata super-hero di depan Underdog. Hal itu bertujuan agar pembaca sasaran dapat memahami bahwa Underdog merupakan nama seorang super-hero. Dengan demikian, penulis menerapkan prosedur penerjemahan penjelasan tambahan.

Red herring $::$ petunjuk palsu

Melalui idiom red herring, penulis novel melakukan permainan kata tipe pun. Dalam konteks cerita, red herring mengacu pada dua hal yang berbeda, yaitu idiom dan nama ikan yang diawetkan. Dalam konteks cerita, pemahaman Judy dan Rocky tentang red herring berbeda. Menurut Judy, red herring merupakan petunjuk yang mengecoh (idiom), sedangkan menurut Rocky, red herring adalah ikan yang berbau busuk (makna denotatif). Dalam kasus ini, penulis memutuskan untuk memadankan idiom red herring dengan parafrasa petunjuk palsu. Menurut laman http://archive.kaskus.us (diakses tanggal 9 Juli 2011), petunjuk palsu mempunyai makna petunjuk yang digunakan untuk mengalihkan perhatian dari jejak kriminal yang sebenarnya. Dengan demikian, penulis menerapkan prosedur penerjemahan parafrasa.

\section{SIMPULAN}

Dalam novel anak ini banyak ditemukan permainan bahasa. Permainan bahasa yang dilakukan penulis novel terjadi pada tataran ejaan, bunyi dan kata. Permainan pada tataran ejaan (permainan ejaan) berupa penggunaan ejaan secara kreatif. Sebagai solusi atas masalah penerjemahan permainan ejaan, prosedur penerjemahan adaptasi dapat digunakan. Alasannya, belum tentu dalam satu bahasa (BSu) memiliki kata yang sifat ejaan sama dengan bahasa lain (BSa). Oleh karena itu, ketika memberikan padanan pada permainan ejaan, penerjemah harus mengadaptasi permainan ejaan itu. Penerjemah harus mencari kata yang mempunyai kemiripan sifat terdekat 
dengan kata dalam BSu. Dengan demikian, efek permainan ejaan dapat tercapai.

Prosedur penerjemahan yang digunakan untuk mengatasi masalah penerjemahan permainan bahasa pada tataran bunyi lebih beragam. Meskipun demikian, prosedur kuplet lebih mendominasi. Pada permainan bahasa jenis ini, sebagian besar bentuk permainan bunyi berubah, seperti rima berubah menjadi asonansi; asonansi dan aliterasi berubah menjadi rima. Perubahan bentuk permainan bunyi itu berpengaruh pada prosedur penerjemahan yang digunakan. Variasi prosedur penerjemahan yang digunakan bertujuan untuk memperoleh efek permainan bunyi yang serupa dengan permainan bunyi TSu. Meskipun demikian, pada kasus tertentu, bentuk permainan bunyi tidak mengalami perubahan, seperti pada presto-change-o gonzo yang dipadankan dengan abra ka dabra. Bentuk permainan bunyi TSu dan Tsa sama, yaitu asonansi.

Permainan bahasa pada tataran kata (permainan kata) yang ditemukan dalam novel ini berupa penggunaan kata atau frasa yang mempunyai dua makna (makna idiom dan makna denotatif), serta penggunaan frasa yang menyimpang dari tata bahasa. Prosedur penerjemahan yang banyak digunakan untuk mengatasi masalah permainan kata adalah parafrasa. Prosedur ini digunakan ketika permainan kata berupa idiom. Idiom dalam BSu belum tentu memiliki padanan idiom dalam BSa.
Selain itu, suatu istilah bidang tertentu dalam BSu juga belum tentu mempunyai padana serupa dalam BSa. Oleh karena itu, prosedur parafrasa diterapkan. Meskipun demikian, penerjemah harus tetap mempertahankan efek permainan kata $\mathrm{TSu}$ dalam TSa.

Selain berupa kata atau frasa, permainan bahasa juga dapat berupa nama tokoh. Untuk permainan bahasa jenis itu, penerjemah dapat mengutip langsung (transferensi). Apabila tokoh itu tidak begitu dikenal oleh pembaca sasaran, penerjemah dapat memberikan penjelasan tambahan. Hal yang terpenting dalam memberikan padanan pada permainan bahasa adalah tetap mempertahankan efek permainan bahasa $\mathrm{BSu}$ dalam $\mathrm{BSa}$. Terkadang penerjemah harus berani keluar dari makna kata TSu. Penerjemah dapat menggunakan kata yang secara semantis tidak mempunyai makna yang sama dengan $\mathrm{TSu}$, tetapi efek yang ditimbulkan serupa dengan efek permainan bahasa TSu.

\section{UCAPAN TERIMA KASIH}

Penulis mengucapkan terima kasih kepada Mitra Bestari yang turut menyumbangkan saran-saran perbaikan yang sangat bermanfaat bagi perbaikan artikel ini.

\section{DAFTAR PUSTAKA}

Cook, G. (2000). Language play, language learning. New York: Oxford University Press.

Hatim, B., \& I. Mason. (1990). Discourse and the translator. Essex: Longman. 
Keraf, G. (1984). Diksi dan gaya bahasa: komposisi lanjutan I (edisi yang diperbarui). Jakarta: Gramedia Pustaka Utama.

Larson, M. (1984). Meaning-based translation: a guide to cross-language equivalence. Lanham: University Press of America.

Muhammad, K. (1988). Perbincangan gaya bahasa sastera. Kuala Lumpur: Dewan Bahasa dan Pustaka.

Munday, J. (2001). Introducing translation studies: theories and applications. Oxon: Rouledge.

Newmark, P. (1988). A textbook of translation. London: Prentice Hall.

Nida, E.A.\&Charles R. Taber. 1974. The Theo$r y$ and Practice of Translation. Leiden: EJ. Brill.

Nilson, D. 1978. Language play: an introduction to language play. Massachusetts: Newbury House Publisher.

Sarumpaet, R.K. (1975). Bacaan anak-anak: suatu penyelidikan pendahuluan ke dalam hakekat, sifat, dan corak bacaan anak-anak serta minat anak pada bacaannya. Skripsi. Depok: Universitas Indonesia.

Sumardjo, Jacob, \& Saini K.M. (1991). Apresiasi kesusastraan. Jakarta: Gramedia Pustaka Utama.

Toha-Sarumpaet, R.K. (2010). Pedoman penelitian sastra anak. Jakarta: Yayasan Pustaka Obor Indonesia.

Vinay, J. \& J. Darbelnet. (2004). A methodology for translation. Dalam L. Venuti (ed). A translation studies reader (ed. ke-2). (hlm. 128-137). New York: Routledge.

Wellek, R. \& Warren, A,. (1977). Teori kesustraan. (terj. Melani Budiana). Jakarta: PT. Gramedia.

Zoest, A.A. 1991. Fiksi dan Non Fiksi Dalam Kajian Semiotik (terj. Manoekmi Sardjoe). Jakarta: Intermasa. 